\title{
The virtual forum as a teaching tool in the nursing degree internship or placements
}

El foro de discusión como herramienta docente en prácticas tuteladas del grado en enfermería O fórum de discussão como uma ferramenta de ensino na prática supervisionada do curso de enfermagem

Natalia Hernández Hita*; Cristina Arias Mancebo**; Laura Visiers Jiménez ${ }^{* * *}$; David Peña Otero****

\begin{abstract}
Background: The virtual forum is one the active methodologies taking advantage of the possibilities offered by the information and communication technologies. They are an asynchronous communication method used to develop essential skills among nursing degree students, including their writing, reflection, and critical thinking skills.

Objective: To reflect on the use of the virtual forum as a teaching tool in supervised practice.

Main topics under analysis: In the Nursing Degree of the University Center of Health Sciences San Rafael-Nebrija, discussion fora were implemented in $2014 / 2015$ as a directed activity within the digital portfolio included in the Intermediate Internship of the $3^{\text {rd }}$-year of the Nursing Degree (4 years in total).

Conclusion: As an innovative teaching tool, discussion fora are useful for the acquisition or update of knowledge through literature searches and for the development of students' synthesis and prioritization skills, promoting their self-learning.
\end{abstract}

Keywords: thinking; nursing faculty practice; group processes; diffusion of innovation

\section{Resumen}

Marco contextual: Entre las metodologías activas que aprovechan las posibilidades que ofrecen las técnicas de la información y la comunicación se encuentran los foros de discusión, como método de comunicación asincrónico, utilizados para desarrollar competencias esenciales entre los estudiantes del grado en Enfermería, como la capacidad de redacción, reflexión y pensamiento crítico.

Objetivo: Reflexionar sobre el uso del foro virtual como herramienta didáctica en prácticas tuteladas.

Principales temas en análisis: En el grado en enfermería del Centro Universitario de Ciencias de la Salud San Rafael-Nebrija se implementó, en el curso 2014-2015, el uso de foros de discusión como actividad dirigida dentro del portafolio digital incluido en la asignatura de Prácticas Tuteladas Nivel Medio del 3. ${ }^{\circ}$ curso.

Conclusión: El foro de discusión como herramienta de innovación docente es útil para la adquisición de conocimientos o la actualización de los mismos a través de la realización de búsquedas bibliográficas y para desarrollar la capacidad de síntesis y priorización de los estudiantes, lo que favorece su autoaprendizaje.

Palabras clave: pensamiento; práctica del docente de enfermería; procesos de grupo; difusión de innovaciones

*RN, San Rafael-Nebrija Health Sciences University Center. University Antonio de Nebrija, 28036, Madrid, Spain [nhernandezh@alumnos.nebrija.es]. Contribution to the article: literature review, data collection, analysis of results, article writing. Address for corresponliterature review, data collection, analysis of results, article
dence: Paseo de La Habana 70 bis, 28036 , Madrid, España.

**RN, San Rafael-Nebrija Health Sciences University Center. University Antonio de Nebrija, 28036, Madrid, Spain [cariasm1@alumnos.nebriia.es]. Contribution to the article: literatu28036, Madrid, Spain [cariasm1@alumnos.nebrija.es].Contr
re review, data collection, analysis of results, article writing.

****Ph.D., Adjunct Professor, San Rafael-Nebrija Health Sciences University Center. University Antonio de Nebrija, 28036, Madrid, Spain [lvisiers@nebrija.es].Contribution to the article: Project and article design, data analysis and interpretation, analysis of results, article writing.

*****Ph.D., Professor, San Rafael-Nebrija Health Sciences University Center. University Antonio de Nebrija, 28036, Madrid, Spain [dpena@nebrija.es]. Contribution to the article: Project and article design, data analysis and interpretation, analysis of results, article writing.

\section{Resumo}

Enquadramento: Entre as metodologias ativas que aproveitam as possibilidades oferecidas pelas técnicas de informação e comunicação, estão os fóruns de discussão, como método de comunicação assíncrona, usado para desenvolver competências essenciais entre os estudantes de Enfermagem, como a capacidade de escrever, reflexão e pensamento crítico.

Objetivo: Refletir sobre o uso do fórum como ferramenta pedagógica na prática supervisionada.

Principais tópicos em análise: $\mathrm{Na}$ Licenciatura em Enfermagem do Centro Universitário de Ciências da Saúde, San Rafael-Nebrija foi implementado, no curso 2014-2015, o uso de fóruns de discussão como atividade direcionada dentro do portfólio digital incluído no assunto de Estágios Tutelados Nível 3 do terceiro ano.

Conclusáo: $\mathrm{O}$ uso do fórum de discussão como ferramenta de inovação pedagógica é útil para a aquisição de conhecimento ou atualização do mesmo através da realizaçáo de pesquisas bibliográficas e para desenvolver a capacidade de síntese e priorizaçáo dos alunos, o que favorece a sua auto-aprendizagem.

Palavras-chave: pensamento; prática do docente de enfermagem; processos grupais; difusáo de inovaçóes 


\section{Introduction}

Teaching is the art of transmitting knowledge. One of the key objectives of the European convergence process is to promote a methodological change in higher education, producing pedagogical materials and "resources capable of providing high-level knowledge and facilitating autonomous learning" (García-Carpintero Blas et al., 2017, p. 24).

Contrary to the classical teaching model or old educational paradigm, focused on the teacher's activity with explanatory and master methods of transmission of knowledge, "today calls for a type of teaching focused on the student's autonomous activity, which assumes the existence of learning objectives or outcomes focused" on the student, who should become responsible for their knowledge acquisition process (García-Carpintero Blas et al., 2015, p. 1). The development of the individual and continuous self-learning capacity will facilitate the student's adaptation to the demands of a constantly changing world. To this end, "the so-called active methodologies, in which students play a leading role" are essential because they are the ones taking on the challenge of learning, acquiring and building knowledge based on the activities designed by the teacher (García-Carpintero Blas et al., 2017, p. 25).

With the arrival of the so-called Digital Era, the teaching methods have evolved and new technologies have given way to a new teaching concept where information and communication technologies (ICT) are of utmost importance. These technologies are defined as "the set of tools, media, and channels used in the treatment and access to information", which allow new ways of access to communication, participation and cultural recreation in a single format - the digital format (López, 2014, p. 192). Within their applications, ICT can be considered as a tutorial tool in its three aspects: electronic, assisted, and smart. Various authors believe that there is an interrelationship between economic growth and knowledge, proposing that ICT can be used in the teaching process as an object of study, working tool or teaching method (Garcia Serrano, Carrillo Hernández, \& Hidalgo Cabrera, 2012).

According to Order CIN 2134/2008, of 3 July (Orden CIN 2134/2008, de 3 de julio), which sets out the requirements for verification of official university degrees that qualify for the exercise of the nursing profession, nursing degree students must achieve basic competencies such as the preparation and defense of arguments and solving problems in the field of nursing, the transmission of information, ideas, problems, and solutions to both a specialist and non-specialist audience, and transferable skills such as the ability to communicate correctly or proper use (ICT).

In the nursing degree, ICT aim to improve the educational quality of future nurses because they are a means of providing clinical, administrative, teaching, and research support, which offer better career opportunities and help the teacher to systematically follow-up on student's acquisition of knowledge (Cuellar Espinoza, Cuellar Espinoza, Muñoz Bernal, \& Herrera Martínez, 2016). In addition, university education is oriented toward the development of professional skills, which have an impact on the update of procedures and indicators of university evaluation. This pedagogical paradigm guides the teaching methodologies towards student's autonomous learning based on the acquisition and development of academic and professional competencies. These skills range from knowing how to do it and being able to do it until wanting to do it, interacting closely with the learning outcomes, that is, what the student is expected to be able to put into practice after completing an educational program. This program will include the acquisition of both generic skills, which will provide basic knowledge and skills for social life, and specific skills, which will enable their integration into a specific employment sector (García-Carpintero Blas et al., 2017).

Critical thinking is a cognitive process which includes the rational analysis of the information to facilitate clinical reasoning in order to make informed decisions before issuing a judgment. With regard to the nursing profession, given its potential impact on care, an improvement in the quality of care depends, to a large extent, on the development of critical thinking skills to improve the diagnostic decisions. The complexity and ever-changing nature of human responses, along with the variability of the health care centers and the need for evidence-based, patient-centered care, have transformed critical 
thinking into a highly important competence in education and professional practice $(\mathrm{Zu}-$ riguel Perez et al., 2015).

The methodological strategies will depend on the type of competency to be developed, the group characteristics, and the scenario where the activity will be performed. According to Miguel Díaz (2005, p. 23), the teaching process "in the form of seminars can be accomplished by using case studies, problem-based learning, projects or cooperative work". Whatever the option selected, the only way to ensure that students are involved in the learning process is their active participation in activity management.

Glen and Hight (1992) wrote one of the first articles on the use of portfolios in nurses' training by analyzing this pedagogical tool as an educational and assessment strategy. According to McMullan (2006), portfolios have been used in nursing education both for personal and professional development. According to Hill (2012), the nursing portfolio has been suggested as an alternative approach in the ongoing and formative assessment of the complex skills, with the intent that it will counteract the limitations of conventional assessment.

Today, in the field of education, the use of ICT has spread rapidly, as students and teachers make an intensive use of technological devices that allow them to be constantly communicating. For teachers, the use of ICT has become a necessity that provides them with an added value in the teaching-learning processes (Andrés Sánchez, Egues Artola, Erdocia, \& Marieta Gorriti, 2015). However, despite the multiple benefits of ICT, they are sometimes impossible to implement because of educational centers' difficulty to provide the necessary resources for their implementation, as well as the teachers' lack of knowledge and use of ICT since they often prefer a more traditional type of education (López, 2014).

Technology allows access to online educational platforms, which facilitate the collaboration between teachers and students (Andrés Sánchez et al., 2015). One of these educational platforms is the discussion forums or virtual forums, which are defined as "spaces for academic discussions which contribute to the development of strategic critical think- ing based on dialogue" (Castro Méndez, Suárez Cretton, \& Soto Espinoza, 2016, p. 25). Critical thinking is a process that can be explored and then assimilated during the academic period or in the professional activity. Nevertheless, some problems remain to be resolved, such as the ambiguous nature of the concept, its measurement, and the strategies for better developing it (Zuriguel Pérez et al., 2015).

Discussion forums are designed to promote discussion without the need to exhaust the subject under discussion. In virtual environments, the teacher's role is to facilitate, advice, and guide students to select the most appropriate information sources (Castro Méndez et al., 2016). For teachers, the forum allows them to get to know the students better, their interest in the subject under discussion, and perform an ongoing assessment. For students, the forum contributes to clarify the meaning of written texts and promote critical thinking (González Hernando, Martín Villamor, \& Arribas Leal, 2012). Therefore, the discussion forum promotes the development of student's self-learning throughout their academic path and transforms the teacher into a facilitator in the search for learning experiences by encouraging the development of critical thinking (Cuenca Cartagena, 2015). Thus, the discussion forum is a two-way communication, with four characteristics (Rodolfo Lara, 2015): 1) has to be a space of debate on academic subjects; 2) of group collaboration; 3) of free meetings; and 4) has to promote the development of technological skills.

A discussion forum must meet certain requirements to promote an adequate level of quality of the educational interaction (Rodolfo Lara, 2015): 1) it has to be a time-bound activity, with a beginning and an end; 2) the students' participation has to change their knowledge; and, finally, 3) it must allow the student to further enhance their knowledge on a given topic, clarify their ideas, check different information sources, and to quote specific authors contributions. According to Rodolfo Lara (2015, p. 75), students' follow-up in virtual forums aims "to be a management support tool, contribute to the development of the participants' management skills by analyzing why a given activity was not completed, and 
be a source of information for student's assessment".

This follow-up tool is very useful for the nursing mentor because it allows them to monitor the students' progress, guide them, and promote their participation (Rodolfo Lara, 2015). In addition, to assess the participation and knowledge acquired through the forum, there is a fivestep coding system with different levels to establish the degree of interaction. In each phase, the levels describe the type of interaction. These phases are: 1) comparing information; 2 ) dissonance and inconsistency of ideas; 3) negotiation or co-construction of knowledge; 3 ) testing and modification; and, finally, 4) agreements and applications (Carrasco, Carrillo, Bazley, Vergara, \& Contreras, 2017).

The studies by Eligio Mendoza, Gómez Zermeno, and García Mejía (2016) and Rodolfo Lara (2015) argue that the discussion forums which follow an appropriate methodology generate an atmosphere of debate that promotes the development of both critical thinking skills and digital skills in students. Critical thinking is the mirror of metacognition, that is, the reflection of thinking about thinking; a way of systematizing, rationalizing, and clarifying the cognitive process focused on decision-making, as a proposal characterized by internal motivation to solve problems and make decisions and as a focused and reflexive thought to consider the decision to make, including the ability to compare alternatives (Peixoto \& Peixoto, 2017). On the other hand, the training strategies developed through reflective practice are a way of developing nursing student's professional skills. Throughout their academic path, teachers perceive that students learn new knowledge, attitudes, and skills that allow them to become aware of and rethink their prejudices and facilitate the improvement of the quality of care delivery (López Rodrigo, Cardó Vila, Vives Abril, Claudi Sumalla-Gómez, \& Moreno Poyato, 2017). With the purpose of promoting reflection and critical thinking in students, preferably health sciences students, Graham Gibbs put forward a reflection model (Gibbs, 1988), known as the Gibbs Cycle, so that future health professionals could learn to assess and reflect on certain situations. The cycle consists of six steps: the objective de- scription of the event; the identification of the ethical issues and how they influence student's feelings, thoughts and feelings; the subjective reasoned theoretical reflection; the analysis of the assessment of their own behavior in the event where the student must be critical and justify their behavior based on the literature; and conclusion and action plan for future similar events through a decisive action plan. The issue of plagiarism should be highlighted. According to Cevallos Torres, Guijarro Rodríguez, and Domínguez Rivas (2016), it is a serious concern in academic settings that affects university students. Students often (more than $60 \%$ of the students) include extracts of texts written by another person and submit the document as their own work. To a large extent, this happens due to the increase in the number of available online resources and the lack of reading, analysis, and synthesis skills. Thus, through the forum, other skills could be simultaneously enhanced which could reduce plagiarism in academic papers such as the improvement of writing skills and the identification of different information sources and their correct citation and referencing in the format required by the university and the faculty (Smith, 2017).

Several studies address the utility of virtual forums as innovative teaching tools in the nursing field. González et al. (2012) aimed to determine nursing students' perceptions of the utility of virtual forums in their academic training. To this end, four forums were planned for the subject of Sexual and Reproductive Health during a semester with the purpose of further enhancing the topics taught in the lectures and promoting reflective and critical thinking. With regard to the students' perception of utility, $93.2 \%$ of them considered that the forum had allowed them to express themselves freely, compare their ideas, and be participatory; $86 \%$ of them considered it to be a convenient tool; and, finally, $69 \%$ of the students believed that it was a useful tool as a supplement to their training. In addition, $45 \%$ of the students considered that the forum had contributed to deepening their knowledge, that it had increased the interaction between students and teachers, and that it was a useful tool in the evaluation process to achieve a more compre- 
hensive view of the teaching-learning process. In this same line, Andrés Sánchez et al. (2015) conducted a study with the purpose of identifying the usefulness of using virtual fora for learning a given subject. The teacher of the subject of Chemical Foundations of Engineering created a forum for discussion of doubts about the subject in which the teacher proposed a series of problems to be solved. A survey was conducted that assessed five items: 1) Satisfaction; 2) Promotion of collaborative work; 3) Contributions to learning; 4) Development of skills; and 5) Assessment system. The following results were obtained in this study: a) Satisfaction: $86 \%$ of respondents were satisfied with using the forum and stated that they would prefer that the forum remained active throughout the subject; b) Contribution to the promotion of collaborative work: students recognized that it promotes the interaction between students and between teachers and students.

This study highlights that the virtual forum increases the interaction between students and between teachers and students; students see it as a useful and complementary tool in their training, which helps them to enhance their knowledge. They also claim that the use of the forum requires a greater commitment from the student which will be rewarded at the end. It highlights that the student must be motivated, which is a responsibility of the nursing mentor (Andrés Sánchez et al., 2015).

In ICT, Cuenca Cartagena (2015) considers the virtual forum to be a digital tool that enables the exchange of information between students and faculty on a given topic, which promotes both autonomous and group work and provides a collaborative learning environment. One of the main objectives of the virtual forum is to develop the reflective and critical thinking of students who asynchronously participate in it.

It should be noted, however, that there is no universally accepted conceptual framework for critical thinking. The studies suggest that these tools need to be consolidated and adapted both in the clinical and educational environment, as well as that there is little evidence of the regular evaluation of the competence (Zuriguel Pérez et al., 2015).

In view of the above, the objective of this study is to reflect on the use of the virtual forum as a tool for enhancing the use of evidence-based nursing interventions.

\section{Development}

In 2014/2015, at the San Rafael-Nebrija Health Sciences University Center, virtual fora were implemented as a directed activity within the digital portfolio included in the Internship placement subject of the 3rd-year of the Nursing Degree. It should be carried out by groups of 3 to 5 students and supervised by the subject teachers during the students' clinical rotations. The subject was taught from January to July 2017, with a workload of 30 European Credit Transfer System (ECTS), 21 of which correspond to the three 5 -week rotations carried out by the students at different units and hospitals. The remaining 9 ECTS correspond to the studentss portfolio (Peña Otero \& Visiers Jiménez, 2017). At the suggestion of the teacher, the portfolio is divided into a reflective diary, a discussion forum, a clinical case study, and in-person sessions. This article examines the first two activities - the discussion forum developed within a group and the reflective diary, developed by the student individually. Both activities had a clear purpose to develop critical thinking.

In the discussion forum, each group of students should deepen the critical reflection based on the scientific evidence of a procedure related to intermediate care. Specifically, interventions based on the Nursing Interventions Classification (NIC). The rest of the groups should, on a weekly basis, provide inputs that reflect their own clinical experience in the internship. In the forum, students were expected to acquire the competencies and achieve the learning outcomes assessed through the rubric developed in Table 1 . The evaluation of the process would correspond to $15 \%$ of the total grade.

In addition, after each clinical rotation, students had to create a reflective diary, based on the Gibbs Cycle (Gibbs, 1988), with the purpose of reflecting on their daily practice. Each diary corresponded to $5 \%$ of the total grade. After submission, all of them were assessed to promote continuous learning. 
Table 1

Scoring rubric of the virtual forum

Deadline for submission CG.2

(PASS or FAIL) If this criterion is not met, the score will be 0

Participation/Contributions to other groups (20\%) CG.10; CG.4; CG.20

Participation YES/NO (weekly). The weight of each contribution will correspond to the number of interventions planned for each rotation

\begin{tabular}{llcccc}
\hline Level of & Very poor & Insufficient & Sufficient & Good & Outstanding \\
performance & $(0-2.9)$ & $(3-4.9)$ & $(5-6.9)$ & $(7-8.9)$ & $(9-10)$ \\
\hline
\end{tabular}

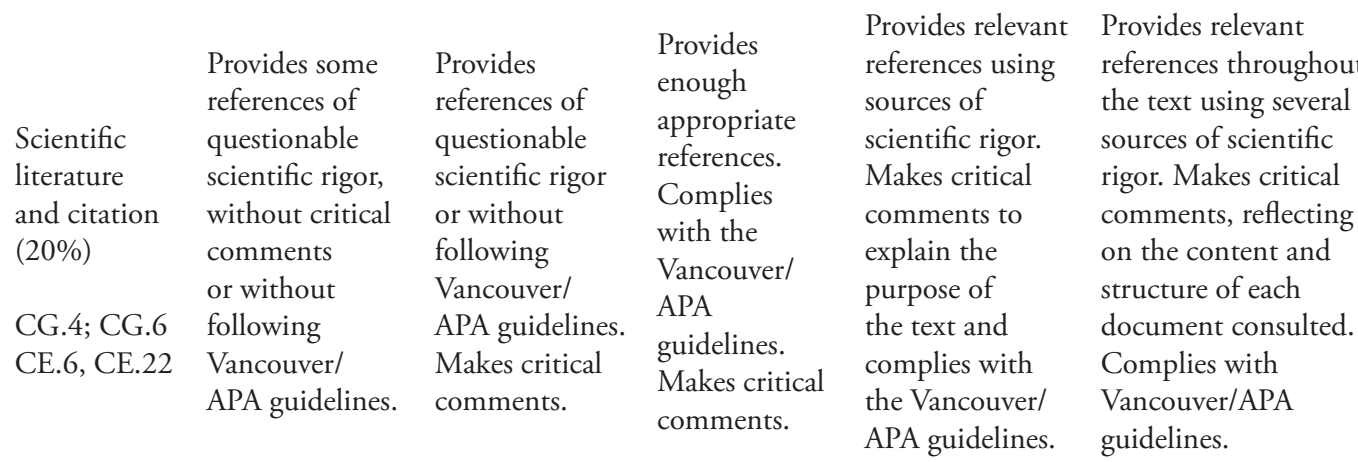

$\begin{array}{lll} & & \\ \text { Rationale } & \begin{array}{l}\text { The documents } \\ \text { produced have } \\ \text { documents } \\ \text { include enough } \\ \text { data, they are } \\ \text { disorganized. }\end{array} \\ \text { VG.7; } & \begin{array}{l}\text { very few data } \\ \text { which are } \\ \text { disorganized. }\end{array} & \begin{array}{l}\text { The reflive } \\ \text { statements are } \\ \text { not based on } \\ \text { arguments. }\end{array}\end{array}$

The data selected are enough, with an organized structure divided into sections and justified.

There is little evidence of independent reflection.
Data selection

is wide and Data selection is adjusted to the fully adjusted to situation. It has the situation It an organized has an organized structure divided structure divided into sections into sections. Data and justified. are justified using Data are justified consistent arguments using consistent and reflections. arguments. The reflections It contains demonstrate an some evidence original and in-depth of independent reasoning. reflection.
Writing and presentation $(15 \%)$

CG.3
Frequent errors in writing. The different sections are not well organized. It has too many spelling, grammar, and syntax errors.
Frequent errors in writing. The different sections are not well organized. It has spelling, grammar, and syntax errors.
Incomplete

organization and professional language with some errors. It does not have spelling, grammar, and syntax errors.
It complies with all the requirements for paper submission. It is well-structured, properly documented and has a good professional language.
It is well-structured. It is expressed in an outstanding manner in the professional language. It uses typography resources that facilitate text understanding. 


\begin{tabular}{|c|c|c|c|c|c|}
\hline $\begin{array}{l}\text { Inclusion of } \\
\text { answer to } \\
\text { comments/ } \\
\text { contributions } \\
(10 \%) \\
\text { CG.10 } \\
\text { CE.6 }\end{array}$ & $\begin{array}{l}\text { Does not } \\
\text { analyze the } \\
\text { difficulties or set } \\
\text { improvement } \\
\text { objectives. Does } \\
\text { not include a } \\
\text { self- evaluation/ } \\
\text { self-criticism } \\
\text { process. }\end{array}$ & $\begin{array}{l}\text { Provides a } \\
\text { commentary on } \\
\text { the difficulty } \\
\text { in selecting } \\
\text { data, but it } \\
\text { does not set } \\
\text { improvement } \\
\text { objectives. } \\
\text { Performs self- } \\
\text { evaluation / } \\
\text { self-criticism } \\
\text { processes, } \\
\text { but does not } \\
\text { identify them as } \\
\text { such. }\end{array}$ & $\begin{array}{l}\text { Analyzes the } \\
\text { difficulties, } \\
\text { sets some } \\
\text { improvement } \\
\text { objectives } \\
\text { but does not } \\
\text { assess them. } \\
\text { Performs self- } \\
\text { assessment / } \\
\text { self-criticism } \\
\text { process, but } \\
\text { does not } \\
\text { establish } \\
\text { measurable } \\
\text { criteria for } \\
\text { improvement. }\end{array}$ & $\begin{array}{l}\text { Analyzes the } \\
\text { difficulties, } \\
\text { sets some } \\
\text { improvement } \\
\text { objectives and } \\
\text { assesses some of } \\
\text { them. Includes } \\
\text { self-assessment/ } \\
\text { initial and final } \\
\text { self-criticism } \\
\text { processes with } \\
\text { measurable } \\
\text { criteria for } \\
\text { improvement. }\end{array}$ & $\begin{array}{l}\text { Analyzes the } \\
\text { difficulties, sets } \\
\text { improvement } \\
\text { objectives, and } \\
\text { assesses them } \\
\text { continuously. } \\
\text { Includes self- } \\
\text { assessment/full } \\
\text { initial and final } \\
\text { self-criticism } \\
\text { processes with } \\
\text { measurable criteria } \\
\text { for improvement. } \\
\text { Identifies and } \\
\text { analyzes the evolution } \\
\text { of self-learning. }\end{array}$ \\
\hline $\begin{array}{l}\text { Summary } \\
\text { /guide } \\
(20 \%) \\
\text { CG.1; CG.3; } \\
\text { CG.24 } \\
\text { CE.34 }\end{array}$ & $\begin{array}{l}\text { No guide or } \\
\text { summary of } \\
\text { the proposed } \\
\text { intervention. }\end{array}$ & $\begin{array}{l}\text { Presents a guide } \\
\text { or a summary } \\
\text { but does } \\
\text { not include } \\
\text { a critical } \\
\text { justification. }\end{array}$ & $\begin{array}{l}\text { Presents a } \\
\text { guide or a } \\
\text { summary of } \\
\text { the proposed } \\
\text { intervention, } \\
\text { with a } \\
\text { critical but } \\
\text { not relevant } \\
\text { justification. }\end{array}$ & $\begin{array}{l}\text { Presents a guide } \\
\text { or summary of } \\
\text { the proposed } \\
\text { intervention, } \\
\text { with a relevant, } \\
\text { critical but } \\
\text { outdated } \\
\text { justification. }\end{array}$ & $\begin{array}{l}\text { Presents a guide } \\
\text { or summary of the } \\
\text { intervention with } \\
\text { updated and relevant } \\
\text { clinical justification. }\end{array}$ \\
\hline
\end{tabular}

Note. CG.1 = Capacity for analysis and synthesis; CG.2 = Capacity for organization and planning; CG.3 = Oral and written communication in the native language; CG.4 = Knowledge of a second language; CG.6 = Elementary computing skills; CG.7 = Information management skills; CG.10 = Ability to work autonomously/in an interdisciplinary team; CG.14 = Critical thinking; CG.20 = Creativity; CG.24 = Initiative and entrepreneurial spirit; CE.6 = Capacity to accept responsibility for your own learning and professional development, using evaluation as a means to reflect on and enhance your performance and improve the quality of the services provided; CE. $22=$ Relevant knowledge of and ability to apply technological and computing skills in healthcare; CE. $34=$ Ability to realize that patient well-being is achieved through the combination of resources and actions of the social/healthcare team members.

A total of 32 enrolled students were enrolled in the subject, of whom 3 participated in the ERASMUS+ program and were not involved in these portfolio activities. In the sample of 29 evaluated students, the subject's mean grade was 6.80: 2 of the students reached the classification of outstanding (1 refers to honor's registration), 24 good, and 3 failed. With regard to the portfolio, the mean grade of the virtual forum was 7.67. The mean grade of the three reflective diaries was 6.64 (Figure 1). 


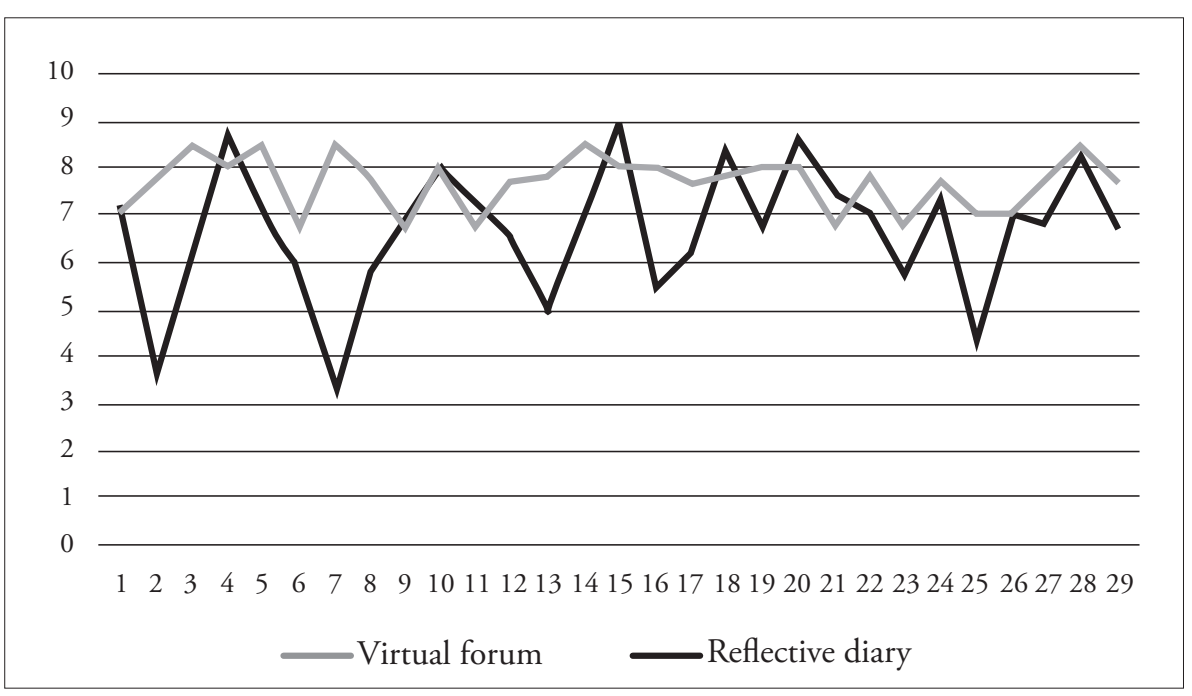

Figure 1. Evaluation - mean grades.

After the experience of implementation of this teaching activity among the students of the Nursing Degree enrolled in the internship course (intermediate), at the end of the 2016-2017 academic year, a voluntary and anonymous questionnaire was distributed (Figure 2). A total of 14 students $(N=29)$ answer the questionnaire.

In relation to the first question on what are the benefits for students' training of searching for scientific evidence on Nursing Interventions Classification through the virtual forum, students reported that it has provided them with knowledge, literature search skills, and ability to synthesize and prioritize information. However, nearly $30 \%$ of students re- ported that the forum had no or very little impact on their training.

With regard to the question on the score assigned to the virtual forum, it should be noted that the mean score was 5.30 out of 10 . In the open-ended question to suggest changes to the forum, the answers mostly focused on the duration of the topic proposed for each week, the composition of the work groups and the work method, preferably individual. Finally, with regard to the implementation and integration of the forum contributions into their daily clinical practice, more than $70 \%$ of the respondents reported that they would do it as much as possible.

\section{QUESTIONNAIRE ABOUT THE VIRTUAL FORUM}

\section{What were the benefits to your training of searching for the scientific evidence on Nursing Interventions Classification through the virtual forum?}

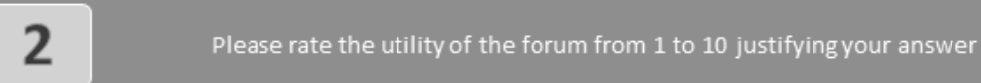

$3 \quad$ How would you enhance this activity?

4. Do you apply the knowledge obtained in the forum in clinical practice?

Centro Univ. De Ciencias de la Salud San Rafael-Nebrija. Prácticas Tuteladas Nivel Medio
San Rafael INEBili

Profesores Titulares: Peña Otero, D.; Visiers Jiménez, L

Figure 2. Questionnaire. 
It should be noted that the acquisition of critical thinking skills produces safer and more competent care and that it could also serve to improve diagnostic accuracy and decision-making, yielding more favorable outcomes for patients (Zuriguel Pérez et al., 2015). Therefore, the development of these portfolio activities can be an appropriate teaching strategy to assess critical thinking.

\section{Conclusion}

The majority of respondents agree with the idea that the virtual forum provided them with additional knowledge to their training as future nurses and that, to the extent possible, they try to apply this scientific knowledge into clinical practice.

However, students are not motivated with the actual implementation of this activity. It would possibly generate greater interest among students if the forum focused more on current nursing-related topics or on solving some of the problems they face in their daily clinical rotations.

The use of the virtual forum as a tool for teaching innovation is useful and facilitates student's learning, encouraging critical thinking. The adaptation of ICT consolidates their potential to be used as a procedure tool if it is assumed that it requires greater involvement and dedication by both students and teachers, encouraging the evaluation of critical thinking.

\section{References}

Andrés Sánchez, M. A., Egues Artola, I., Erdocia, X., \& Marieta Gorriti, C. (2015). Foros virtuales: Una herramienta e-learning para fomentar la interactividad y aprendizaje colaborativo. In XII Jornadas Internacionales de Innovación Universitaria. Educar para transformar: Aprendizaje experiencial, Villaviciosa de Odón, Madrid, 20-21 julio 2015 (pp. 855-861). Retrieved from http://hdl.handle.net/11268/4517

Carrasco, P., Carrillo, M. J., Bazley, K., Vergara, A., \& Contreras, A. (2017). Foros virtuales y construcción de conocimiento en profesionales de la salud. Enfermería Universitaria, 14(3), 184-190. doi: 10.1016/j.reu.2017.06.002
Castro Méndez, N., Suárez Cretton, X., \& Soto Espinoza, V. (2016). El uso del foro virtual para desarrollar el aprendizaje autorregulado de los estudiantes universitarios. Innovación Educativa (México, DF), 16(70), 23-42. Retrieved from http:// www.scielo.org.mx/pdf/ie/v16n70/1665-2673ie-16-70-00023.pdf

Cevallos Torres, L., Guijarro Rodríguez, A., \& Domínguez Rivas, L. L. (2016). Factores que inciden en el mal uso de la información en trabajos de investigación científica. Didasc@lia: Didáctica yEducación, 7(4), 57-74. Retrieved from http://runachayecuador.com/refcale/index.php/didascalia/article/ view/1503/848

Cuellar Espinoza, L. S., Cuellar Espinoza, A. G., Muñoz Bernal, J., \& Herrera Martínez, P. (2016). Desarrollo de las TIC en la formación de recursos en enfermería semiescolarizada. REMEIED: $M e-$ morias del Encuentro Internacional de Educación a Distancia, 5(5), 10-24. Retrieved from http://www. udgvirtual.udg.mx/remeied/index.php/memorias/ article/viewFile/295/155

Cuenca Cartagena, V. E. (2015). The virtual forum as a strategy of teaching in higher education. Hamut'ay, 2(1), 23-31. doi: 10.21503/hamu.v2i1.827

Eligio Mendoza, I. M., Gómez Zermeno, M. G., \& García Mejía, I. A. (2016). O desenvolvimento do pensamento crítico mediante o debate assincrônico em fóruns virtuais na educação secundaria. Revista Aletheia, 8(1), 100-115. Retrieved from http:// www.scielo.org.co/pdf/aleth/v8n1/v8n1a06.pdf

Garcia Serrano, M., Carrillo Hernández, M. C., \& Hidalgo Cabrera, Y. (2012). La educación a distancia para potenciar el proceso de enseñanza aprendizaje. Mendive, 10(3), 235-240. Retrieved from http:// mendive.upr.edu.cu/index.php/MendiveUPR/article/viewFile/538/537

García-Carpintero Blas, E., Siles González, J., Martínez Roche, M. E., Martínez de Miguel, E., González Cervantes, S., \& Pulido Mendoza, R. (2015). El estudiante como protagonista de su aprendizaje: La necesidad del uso del portafolio en enfermería dentro del contexto de educación superior. Index de Enfermeria, 24(1-2), 93-97. doi: 10.4321/S113212962015000100021

García-Carpintero Blas, E., Siles González, J., Martínez Roche, M. E., Martínez Miguel, E., Manso Perea, C., \& Álvarez Embarba, B. (2017). Metodologías de enseńanza-aprendizaje en enfermería: ¿Es el portafolio una metodología acorde con el espacio europeo de educación superior? Revista Enfermería Docente, 108, 24-28. Retrieved from http://www. 
revistaenfermeriadocente.es/index.php/ENDO/article/view/439/pdf_375

Gibbs, G. (1988). Learning by doing: A guide to teaching and learnig methods. Oxford, United Kingdom: Further Education Unit.

Glen, S., \& Hight, N. F. (1992). Portfolios: An 'affective' assessment strategy? Nurse Education Today, 12(6), 416-423. doi: 10.1016/0260-6917(92)90132-8

González Hernando, C., Martín Villamor, P., \& Arribas Leal, E. (2012). Utilidad de los foros virtuales en el proceso de enseñanza-aprendizaje: Experiencia en educación superior en enfermería. Revista Paraninfo Digital, 16.

Hill, T. L. (2012). The portfolio as a summative assessment for the nursing student. Teaching and Learning in Nursing, 7(4), 140-145. doi: 10.1016/j. teln.2012.06.005

López Rodrigo, M., Cardó Vila, G., Vives Abril, T., Sumalla-Gómez, E. C., \& Moreno Poyato, A. R. (2017). Significado de la práctica reflexiva en la adquisición y transferencia de competencias comunicativas en enfermería. Revista Rol de Enfermeria, 40(9), 592-599.

López, C. (2014). Uso de las tecnologías de la información y la comunicación en la administración curricular de postrado. Investigación y Postgrado, 29(1), 183-212. Retrieved from http://revistas.upel.edu. ve/index.php/revinpost/article/view/2576/2637

McMullan, M. (2006). Students' perceptions on the use of portfolios in pre-registration nursing education: A questionnaire survey. International Journal of Nursing Studies, 43(3), 333-343. doi: 10.1016/j. ijnurstu.2005.05.005

Miguel Díaz, F. M. (2005). Cambio de paradigma metodológico en la educación superior: exigencias que conlleva. Cuadernos de Integración Europea, 2, 16-27.

Orden CIN/2134/2008, de 3 de julio. Boletín Oficial del Estado no 174/2008. Ministerio de Ciencia e Innovación. Madrid, España.

Peixoto, T. A., \& Peixoto, N. M. (2017). Pensamento crítico dos estudantes de enfermagem em ensino clínico: Uma revisão integrativa. Revista de Enfermagem Referência, 4(13), 125-138. doi: 10.12707/ RIV16029

Peña Otero, D., \& Visiers Jiménez, L. (2017). Grado en enfermeria PCR102: Prácticas tuteladas: Nivel medio. Retrieved from http://www.nebrija.com/ carreras-universitarias/enfermeria/pdf-asignaturas/ practicas-tuteladas-nivel-medio.pdf

Rodolfo Lara, L. (2015). Criterios que se deben considerar en el proceso de seguimiento y evaluación de alumnos que participan en foros virtuales. Signos Universitarios, Anejo 2, 69-80.

Smith, L. S. (2017). Superar el plagio en la formación de enfermería. Nursing: Edición Española, 34(3), 56-58. doi: 10.1016/j.nursi.2017.06.017

Zuriguel Pérez, E., Lluch Canut, M. T., Falcó Pegueroles, A., Puig Llobet, M., Moreno Arroyo, C., \& Roldán Merino, J. (2015). Critical thinking in nursing: Scoping review of the literature. International Journal of Nursing Practice, 21(6), 820-830. doi: 10.1111/ijn.12347 